\title{
Contemporary Oyster Reef Restoration: Responding to a Changing World
}

\author{
Alice H. Howie* and Melanie J. Bishop \\ Department of Biological Sciences, Macquarie University, Sydney, NSW, Australia
}

Globally, there is growing interest in restoring previously widespread oyster reefs to reinstate key ecosystem services such as shoreline protection, fisheries productivity and water filtration. Yet, since peak expiration of oysters in the 1800s, significant and ongoing environmental change has occurred. Estuaries and coasts are undergoing some of the highest rates of urbanization, warming and ocean acidification on the planet, necessitating novel approaches to restoration. Here, we review key design considerations for oyster reef restoration projects that maximize the probability that they will meet biological and socio-economic goals not only under present-day conditions,

OPEN ACCESS

Edited by:

Emma Victoria Sheehan, University of Plymouth, United Kingdom

Reviewed by: Christine Angelini, University of Florida, United States

Philine Zu Ermgassen,

University of Edinburgh, United Kingdom

*Correspondence: Alice H. Howie

alice.howie@hdr.mq.edu.au

Specialty section:

This article was submitted to Conservation and Restoration

Ecology,

a section of the journal Frontiers in Ecology and Evolution

Received: 01 April 2021

Accepted: 15 July 2021

Published: 03 August 2021

Citation:

Howie AH and Bishop MJ (2021)

Contemporary Oyster Reef

Restoration: Responding to a

Changing World.

Front. Ecol. Evol. 9:689915. doi: 10.3389/fevo.2021.689915 but into the future. This includes selection of sites, and where required, substrates and oyster species and genotypes for seeding, not only on the basis of their present and future suitability in supporting oyster survival, growth and reproduction, but also based on their match to specific goals of ecosystem service delivery. Based on this review, we provide a road map of design considerations to maximize the success of future restoration projects.

Keywords: habitat suitability modeling, nature based solutions, site selection, ecosystem services, climate change, substrate, seeding, coastal development

\section{INTRODUCTION}

Growing recognition of the extent to which marine habitats have been degraded and the resulting socio-economic loss has led to heightened efforts to restore these habitats, and the important ecosystems services they once sustained (Duarte et al., 2020). Marine ecosystems underpin important ecosystem services including coastal protection, carbon sequestration, wastewater filtration and fisheries production (Barbier et al., 2011). Hence, their conservation and restoration can assist in adapting to and mitigating climate change impacts, as well as improving human health and well-being (Kabisch et al., 2016; Raymond et al., 2017). This has been recognized by the United Nations in their declaration of 2021-2030 as the decade of restoration, and inclusion of the restoration of marine and coastal habitats as a target in their Sustainability Goals. In contrast to restoration of land-based habitats, marine habitat restoration is, however, in its infancy with the scale of projects often small and the long-term success poor (Bayraktarov et al., 2016; Stewart-Sinclair et al., 2020).

Successful restoration relies not only upon understanding and overcoming factors presently limiting natural recovery, but also in building ecosystems that will persist and provide desired ecosystem services into the future. Historically, the success of ecological restoration was judged according to the extent to which an ecosystem that had been damaged, degraded or destroyed, 
was returned to a previous ecosystem state (McDonald et al., 2016). However, given the pace of global change, site-bound goals of return to a prior ecosystem state are frequently costly, infeasible and even maladaptive (Harris et al., 2006). Instead, more appropriate goals for ecological restoration may be the attainment of the compositional, structural and/or functional attributes of remnant ecosystems or of modeled reference states (McDonald et al., 2016). Furthermore, alongside restoration-the attainment of a previous or reference state-is the increasing use of ecosystem engineers and habitat-forming species as naturebased solutions for mitigating the effects of ongoing climate change and coastal development (Hughes et al., 2005; Byers et al., 2006; Airoldi et al., 2021).

Ecosystems inhabiting coastal and estuarine waters are particularly susceptible to the effects of coastal development and climate change. Over $40 \%$ of the world's human population is concentrated in $4 \%$ of land area within $100 \mathrm{~km}$ from the coast (Burke et al., 2001), and in many parts of the world this coastal population growth is at or above twice national rates (McGranahan et al., 2007). Additionally, many of the world's coasts and oceans are hotspots for climate change. For example, estuaries along the east coast of Australia are warming at rates of almost 4-times that of the global temperature average (Scanes et al., 2020). Consequently, among the environmental changes to which coastal and estuarine ecosystems are increasingly exposed are extreme heat events, acidification, sea-level rise, habitat destruction, invasive species, disease and pollution (Ruesink et al., 2005; Harley et al., 2006; Lotze et al., 2006; Diggles, 2013). Marine restoration and rehabilitation projects are increasing being used to mitigate the effects of such change, providing nature-based filtration, cooling and coastal defense (Hughes et al., 2005; Airoldi et al., 2021). However, the success of such projects depends on the ability of foundational species to tolerate and persist through ongoing environmental change.

Oyster reefs-complex three-dimensional structures created from aggregations of oysters - are among the coastal habitats that are increasingly the focus of restoration efforts (Figure 1). Oyster reefs support diverse and abundant ecological communities, and underpin highly valued ecosystem services such as coastal protection, water filtration, fisheries productivity and carbon sequestration (Grabowski and Peterson, 2007; Alleway et al., 2015). Though once broadly distributed globally across temperate and tropical coastlines, oyster reefs experienced an 85\% decline during the 1700 s to early 1900 s largely due to overharvest using destructive fishing practices (Beck et al., 2011; Zu Ermgassen et al., 2012; Gillies et al., 2018). Despite subsequent reductions in fishing pressure, oyster reefs did not recover, perhaps because dredge harvest removed not only live oysters but also the dead shell base on which oyster reefs accrete, or perhaps due to the emergence of new threats such as disease, declining water quality, warming temperatures and ocean acidification (Beck et al., 2011).

Until recently oyster reef restoration projects were largely confined to the United States, and focused on the eastern oyster Crassostera virginica (Luckenbach et al., 1999) or the Olympia oyster, Ostrea lurida (Brumbaugh and Coen, 2009; White et al., 2009). However, recently efforts have expanded to additional species including Saccostrea glomerata, Ostrea edulis, Ostrea angasi, Magallana (Crassostrea) sikamea, Magallana (Crassostrea) hongkongensis, and new geographic regions including Australia, New Zealand, Europe, and Asia (Fitzsimons et al., 2019, 2020). Key goals of these oyster reef restoration projects may include biodiversity enhancement, nature-based coastal defense, fisheries productivity as well as improvement of coastal water quality (Figure 2; Coen et al., 2007; Gilby et al., 2018; Morris et al., 2019). Additionally, because intertidal oysters can, through the effects of moisture retention and shading, mitigate heat stress to associated organisms, oyster reef restoration may contribute to management strategies aimed at climate change adaptation of biodiversity (McAfee et al., 2017, 2018b).

To maximize the chances of ecological restoration succeeding, projects should have clear and measurable goals at the time of conception, and be responsive to the present and predicted future environmental and social contexts (Figure 2; McDonald et al., 2016). Projects conducted at more degraded sites, or sites that are projected to undergo significant environmental change may require greater restoration inputs than those conducted at less degraded sites (McDonald et al., 2016). At the site-scale, three key environmental requirements must be met in order for reef establishment to occur: (1) site conditions must be suitable for oyster survival, growth and reproduction; (2) there must be hard substrate on which reefs can accrete; and (3) there must be adequate larval supply to support reef growth.

Here we overview key considerations for designing contemporary oyster reef restoration projects that are resilient and resistant to ongoing environmental change. Specifically, we discuss how project goals and present and projected future environmental conditions might influence site selection, and substrate and seed (transplant) selection (where required; Figure 2).

\section{SITE SELECTION}

Historically, the selection of sites for oyster reef restoration was based largely on historical distributions of oysters and on feasibility given regulating frameworks and logistics (Pogoda et al., 2020). However, given the extent and pace of environmental change from historical baselines, whether environmental conditions are suitable for oyster reefs presently, and into the future, is now also a key consideration (Pogoda et al., 2020). In order for oyster reef restoration to be feasible and represent a long-term return on investment, the physicochemical conditions at a site must match the environmental envelope across which gametes, larvae, and adults can survive, and growth and reproduction can occur (Wasson, 2010), under present-day as well as future conditions. Additionally, to maximize the likelihood that the goals of restoration are met, site conditions should facilitate the provision of desired ecosystem services. For example, if the goal of restoration is to increase the productivity of fin-fisheries, connectivity of the oyster reef with other essential fish habitats is required. Consequently, site selection requires knowledge of the environmental tolerances of the oyster species to be restored and the range 

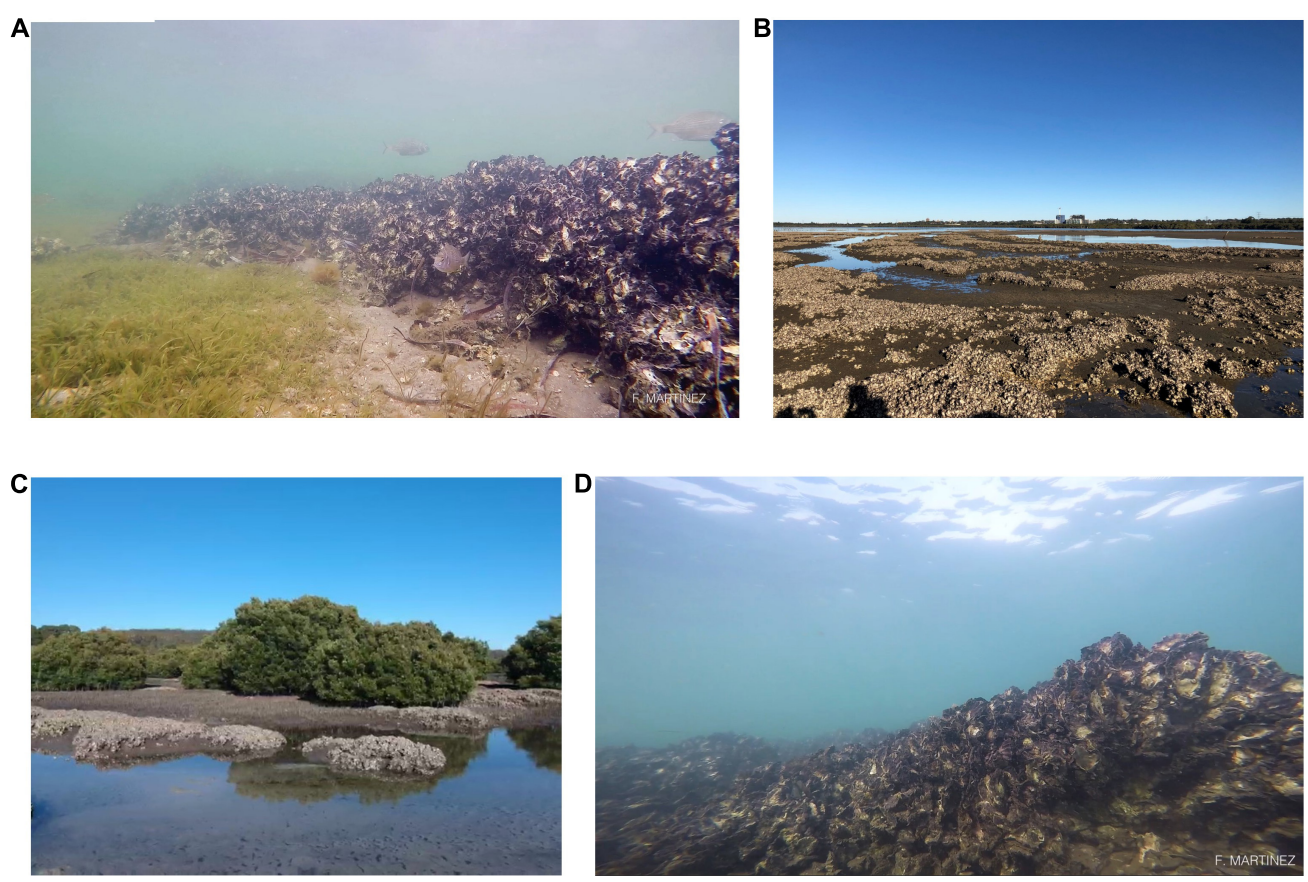

FIGURE 1 | Remnant intertidal Saccostrea glomerata oyster reefs, New South Wales, Australia. Oyster reefs were once distributed globally along temperate and tropical coastlines, but since the 1700s $85 \%$ have been extirpated, including in Australia. Photo credit: Francisco Martinez-Baena (A,B,D) and Juan Muelbert (C).

of conditions across which its reefs provide desired ecosystem services (Figure 2).

Environmental conditions are generally considered the first filter for determining which species can persist at a site, with ecological interactions serving as secondary filters (Kraft et al., 2015). Key environmental considerations when assessing site suitability for oyster reef restoration may include the availability of hard substrate for settlement, as well as water quality parameters (such as temperature, salinity, turbidity, dissolved oxygen, $\mathrm{pH}$, aragonite saturation), geomorphological factors (such as fetch, depth, shoreline slope, and erosion), tidal elevation (depth), food availability, as well as pollution (Soniat and Brody, 1988; Soniat et al., 2013; Theuerkauf and Lipcius, 2016; Chowdhury et al., 2019b; Keller et al., 2019). The optimal conditions for oyster survival and growth, and the thresholds beyond which mortality occurs vary among species. Biological factors that influence post-settlement survival include disease, predation and competition (Powell et al., 1992; Fodrie et al., 2014). At many sites, these conditions are being modified by ongoing climate change and/or coastal development. Consequently, some sites that once supported productive oyster reefs may no longer be suitable, and other sites that were once unsuitable may now or in the future support reef growth (Temmerman et al., 2013). Spatial modeling approaches, that consider environmental, logistic and socio-economic suitability, may assist in site selection.

\section{Shifting Environmental Conditions}

Anthropogenic climate change and coastal development are directly and indirectly modifying many of the key environmental factors that shape the distribution of oysters. Global ocean temperatures have increased by $0.11^{\circ} \mathrm{C}( \pm 0.02 \mathrm{SD})$ on average, in each decade since 1971 (Pachauri et al., 2014), and are predicted to increase between 0.1 and $0.4^{\circ} \mathrm{C}$ per decade for the remainder of the twenty-first century (Stocker et al., 2013; Millington et al., 2019). This warming has already facilitated range expansions of non-native Pacific oysters at several high-latitude locations, such as the Wadden Sea and the Northwest European Shelf (Diederich et al., 2005; King et al., 2021), and enhanced mortality rates of this and other native species at lower latitude locations (Malham et al., 2009; Rybovich et al., 2016). Effects of temperature stress on oysters may be particularly great where they are simultaneously exposed to additional stressors, such as heavymetal contaminants or sub-optimal salinities (Lannig et al., 2006; Rybovich et al., 2016).

Alongside this warming, global climate change is producing a plethora of other environmental changes that are altering site suitability for oyster reefs. For example, increased precipitation in some estuaries such as those of the Northeastern United States is lowering salinity below thresholds required for oyster survivorship (Levinton et al., 2011). Changes in precipitation may also indirectly influence oyster survival, by influencing the prevalence of parasites, many of which have distributions tightly linked to salinity (Powell et al., 1992; Butt et al., 2006; Butt and Raftos, 2008). Additionally, as calcifying organisms, oysters are particularly susceptible to the effects of ocean acidification, with recent research indicating that acidification can lead to alterations of sex determinations and sex ratios, whilst also reducing upper thermal and lower salinity tolerances (Parker et al., 2017, 2018). The rate and extent to which estuaries will be affected by ocean 


\section{Roadmap of design considerations for oyster reef restoration projects}

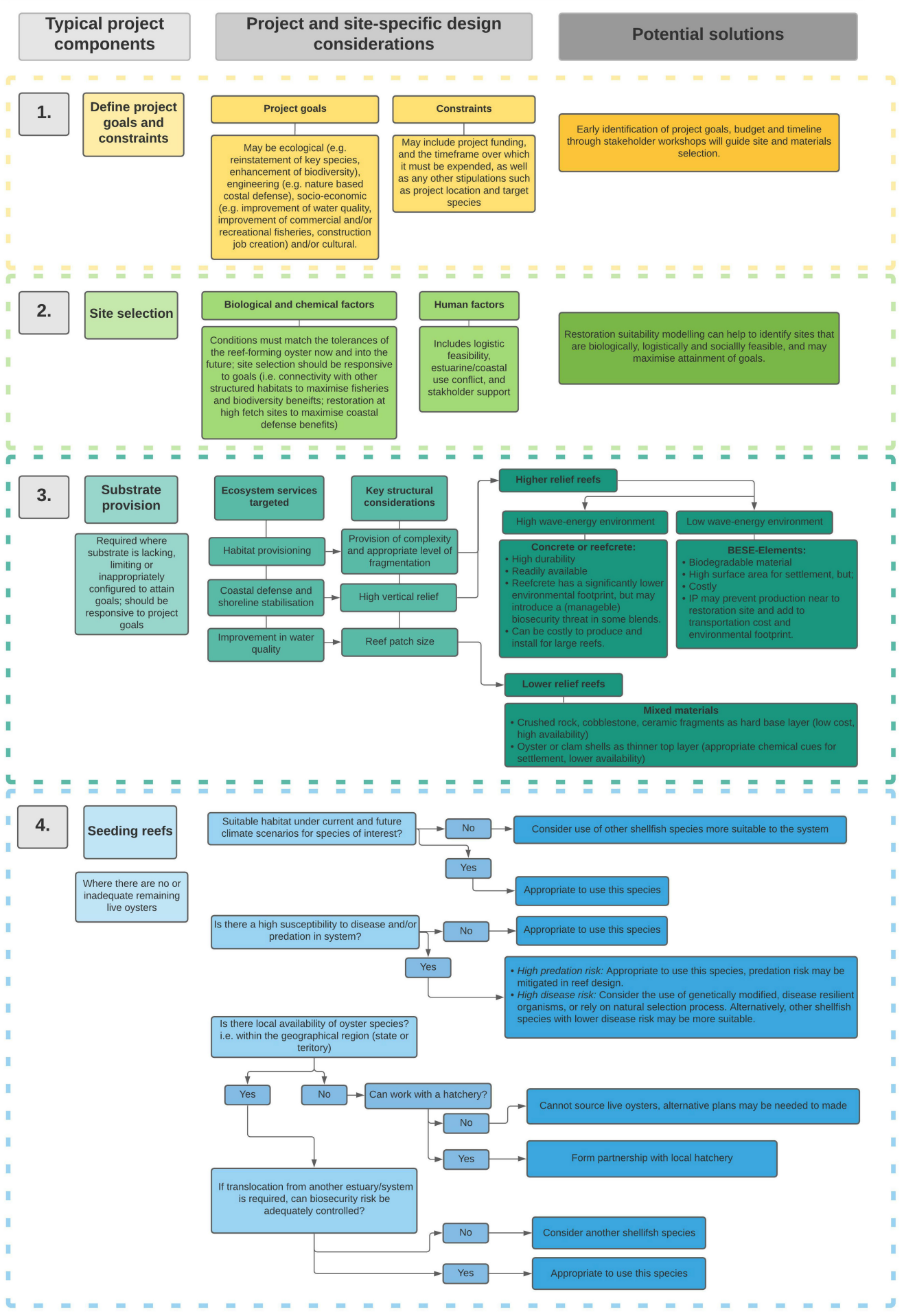

FIGURE 2 | Contemporary roadmap of design considerations for oyster reef restoration projects.

acidification is still somewhat contested (Duarte et al., 2013) and may vary spatially within these (Waldbusser et al., 2011). Sea-level rise and changing wave climates and directions may influence reef growth, though it appears that in at least some instances oyster reef accretion may be able to out-pace sea-level rise (Rodriguez et al., 2014). 
Coastal development is also modifying estuarine and coastal conditions. Amongst the changes that are occurring, a plethora of pollutants are being introduced into estuaries and coasts, from industry, agriculture and urbanization. Some pollutants, such as acid sulfate leachate and hydrocarbons, can have large direct negative effects on oysters (Mahoney and Noyes, 1982; Dove and Sammut, 2007). Others have indirect effects. For example, pollutants such as some insecticides (Ewere et al., 2020) and heavy metals (Gagnaire et al., 2004), can exacerbate effects of disease by weakening an oyster's immune system (Raftos et al., 2014). Where nutrient pollution leads to eutrophication, hypoxic or anoxic conditions can be induced that negatively affect subtidal oyster reef survival and growth (Lenihan and Peterson, 1998; Jeppesen et al., 2018).

Simultaneously, human modifications of flow, for flood mitigation, water security, or through the sprawl of urban structures into the sea can modify factors such as salinity, bottom-water oxygenation and food and larval supply, thereby impacting site-suitability for oyster reefs. For example, where coastal lagoon entrances have been permanently trained open for flood mitigation or navigation, waterways that historically had insufficient water flux to support oyster filter-feeding may now be suitable locations for oyster growth (Garside et al., 2014). In some instances, structures such as breakwaters, culverts and barrages may act as barriers to movement of oyster larvae or dependent taxa (Bishop et al., 2017). In other instances, hard structures may enhance larval supply by acting as an artificial habitat for oysters and other hard-substrate dependent species (Bishop et al., 2017).

Growing human populations in the coastal zone also introduce a range of activities to estuaries that oyster reef restoration may positively or negatively affect. These activities can be commercial (e.g., fishing, aquaculture, shipping), recreational (e.g., swimming, boating, fishing) and/or cultural (e.g., indigenous heritage sites) (e.g., Banks et al., 2016). Consideration of potential sources of conflict and how these may be managed and overcome is critical to development of successful management strategies (Pearson et al., 2016).

Consequently, not only present-day but also projected future environmental conditions and human uses of estuaries should be considered in site selection, to maximize environmental suitability and stakeholder support, and minimize estuarine use conflict.

\section{Restoration Suitability Modeling}

Restoration suitability modeling is increasingly used to assess site suitability for restoration projects (Figure 2). This modeling process utilizes species-habitat relations and geospatial environmental data to create a composite habitat suitability index, with values ranging from unsuitable to highly suitable. Once environmentally suitable sites have been identified, these can then be weighted according to the feasibility of restoration to a give a restoration suitability index. Factors considered when assessing feasibility of restoration might include: estuarine use conflict; distributions of other habitats; regulatory frameworks; and logistics. To identify sites that will support oyster reefs into the future, models should be run for present and predicted future environmental conditions.
Restoration suitability models can be adapted to assess site suitability for key ecosystem services. For example, where the goal of restoration is nature-based coastal defense, data on fetch, wind speed and direction can be overlayed with other biophysical variables to assess the sites where the greatest shoreline stabilization benefits will be obtained (La Peyre et al., 2015). On the other hand, as fish move among habitats of the estuarine seascape to feed, shelter and reproduce (Sheaves, 2009), fisheries benefits may be maximized where the oyster reef is proximate to and connected with other important fish habitats such as seagrass, saltmarsh and/or mangroves (Gilby et al., 2019). A subset of suitable sites identified to be environmentally suitable for restoration, may then be ranked according to stakeholder preferences obtained from participatory mapping exercises, small-scale field trials or more in depth, field-based investigations. Selection of sites that are both environmentally suitable for restoration under present and project future conditions, and are socially accepted will maximize the likelihood of successful restoration.

\section{SUBSTRATE}

Historic dredge harvest of oysters, and subsequent estuarine habitat modification have at many sites removed or buried the shell base required for oyster settlement and reef accretion. At these sites, substrate addition is required for oyster reef restoration. Restoration projects have historically used recycled, fossilized, or dredged native oyster shell as substrate, because it is the natural material on which oyster reefs accrete (Mann and Powell, 2007; Schulte et al., 2009). The increased demand for oyster shells in many systems and the decreasing overall amount of shell have, however, limited the availability and affordability of natural oyster shells for restoration projects (La Peyre et al., 2014; Bersoza Hernández et al., 2018). Additionally in some instances, shell may be infeasible or undesirable to use due to biosecurity regulations (Bushek et al., 2015), increased rates of dissolution of calcium carbonate shell bases in acidifying oceans (Waldbusser et al., 2011), or introduction of microplastics to the environment if shell is deployed in plastic mesh bags (Hunsucker et al., 2021).

Given limitations surrounding use of shell substrate, a diversity of natural and artificial substrates are now being applied to oyster reef restoration (Goelz et al., 2020). These include, but are not limited to: other bivalve shells (e.g., scallop shells, surf clams), crushed limestone or rock, standard concrete (e.g., oyster castles), concrete with various additives often aimed at lowering $\mathrm{pH}$ or resource consumption during manufacture (e.g., Econcrete, Sella et al., 2018; Reefcrete; Dennis et al., 2018) and biodegradable products such as BESE-elements, a zigzag mesh constructed of a potato waste polymer that can be layered to produce a high surface-area structure with protective microhabitat (Herbert et al., 2018; Temmink et al., 2020). These substrates vary in material type and structural attributes, which interact with environmental factors to determine oyster reef development, growth and ecosystem service provision. Additionally these substrates also vary in monetary and environmental cost. Consequently the net benefit they provide 
in supporting oyster reef establishment and ecosystem service provision under present and future environmental conditions may vary markedly.

\section{Structural Attributes}

Complexity, configuration and vertical relief are among the structural attributes of oyster reefs that influence oyster reef development, resilience to environmental stressors and ecosystem service provision (Figure 2 and Table 1). The relative importance of these attributes in building resilient oyster reef restoration projects will depend on project goals as well as on site conditions.

Habitat complexity can provide protective microhabitats to species from stressors and is generally positively associated with biodiversity (Huston, 1979; Coen et al., 2007). Substrates that are either complex by nature (e.g., oyster shell, limestone rock) or are fabricated to incorporate complexity (e.g., concrete blocks with cracks, surface texture, pools and holes; BESE units) can protect oyster recruits from predators as well as environmental stressors such as high temperatures that are being exacerbated by climate change (McAfee et al., 2018a; Strain et al., 2018). Successful oyster recruitment, in turn, leads to complex biogenic habitat, that supports associated invertebrates and juvenile fish (Strain et al., 2020), and can serve as a prey resource for fish and mobile crustaceans (Grabowski and Peterson, 2007; Grabowski et al., 2012). Additionally, complex substrates can facilitate biodiversity while oyster reefs are developing, and still acquiring their own biogenic complexity (Chapman and Blockley, 2009; Ido and Shimrit, 2015; Paalvast, 2015; Strain et al., 2020). Consequently, utilization of complex substrates will be particularly important in environments where high post-settlement mortality limits oyster reef establishment, or where enhancement of native biodiversity is a key ecosystem service goal (Table 1).

Reef size, shape and fragmentation (i.e., whether oyster reefs are continuous or patchy) influence biological processes such as predation, colonization and filtration (Harwell et al., 2011; Hanke et al., 2017) and physical processes such as wave attenuation (Table 2; Allen and Webb, 2011). Reef designs with a large perimeter (e.g., linear reefs or those with rugose edges) benefit species such as fishes and crabs that forage and seek refuge at habitat edges (Griffitt et al., 1999; Hanke et al., 2017). The high habitat provision of rugose perimeters is complemented by their ability to provide thermal refuge for these larger inhabitants (Abele et al., 1986; Sutton et al., 2007). By contrast, designs that maximize interior to edge ratios will benefit invertebrates that reside within reefs, and suffer high predation at their edges (Harwell et al., 2011). Across all habitats, species richness is generally considered to increase with area (Williamson, 1988). Larger reefs may also support higher levels of water quality and filtration services, as these are proportional to the total oyster biomass (Nelson et al., 2004; Grizzle et al., 2006) and greater wave attenuation, which increases with reef width (Allen and Webb, 2011). As thermal amelioration and wave attenuation may positively feedback to enhanced oyster survival, large reefs with rugose edges may confer enhanced resilience of reefs and their inhabitants to warming and increased wave energy.
Vertical relief is particularly important for subtidal reefs in areas of low bottom flow and oxygen, or for intertidal reefs, established in silty areas (Table 1). In the subtidal, a raised substrate can lift oysters out of low-oxygen bottom waters, into faster flowing waters with greater feeding opportunities (Lenihan and Peterson, 1998). This may be considered in urbanized estuaries particularly prone to eutrophication events and seasonal hypoxia of bottom waters. In both intertidal and subtidal settings, vertical relief can also elevate oysters above silty bottoms that may clog gills and impair feeding.

The vertical relief of oyster reefs may also influence the extent to which oyster reefs can function as living, natural breakwaters (Table 1; Grabowski and Peterson, 2007; Grabowski et al., 2012). Like low-crested breakwaters, oyster reefs produce greatest wave attenuation when the crest of the structure is at or above the still water level (Allen and Webb, 2011; Webb and Allen, 2017; Spiering et al., 2018; Wiberg et al., 2019). However, reef crests that spend a greater proportion of their time exposed, while maximizing wave attenuation are not suitable habitat for oysters. Oyster reefs have the benefit over artificial structures in that they can vertically accrete, such that whereas revetments may be over-topped under scenarios of sea-level rise, oyster reefs can potentially keep pace (Grabowski et al., 2012; Rodriguez et al., 2014), serving as natural protection against intertidal habitat loss, shoreline erosion, and property damage (Syvitski et al., 2009; Lin et al., 2012; Temmerman et al., 2013).

\section{Material Type}

Substrates utilized for oyster reef restoration vary in chemistry, color, surface roughness, porosity, density and longevity. These factors interact with environmental conditions to determine oyster settlement and post-settlement survival-key factors underpinning oyster reef development (Table 2).

Substrate chemistry, brightness and micro-texture are key determinants of invertebrate settlement (Crisp, 1976; Pawlik, 1992; Anderson, 1996; Coombes et al., 2015; Ells et al., 2016). Oysters are gregarious settlers, responding positively to the chemical cues of conspecifics (Bonar et al., 1990; Zimme-Faust and Tamburri, 1994). This behavior appears to be driven by peptides (Zimme-Faust and Tamburri, 1994), that may also be associated with biofilms growing on the alkaline surface of some other bivalve shells (e.g., surf clams, scallops) and concrete (Anderson, 1996). Many marine invertebrates including some oysters (Shaw et al., 1970) are negatively phototactic (Crisp, 1976) and settle in higher numbers on to darker than brighter substrates (Ells et al., 2016). The brightness of a substrate may also determine the extent to which it absorbs and re-radiates solar heat (McAfee et al., 2017), potentially making some darker surfaces unsuitable substrates for reef establishment, especially under scenarios of climate warming (McAfee et al., 2017).

The higher alkalinity of concrete ( $\mathrm{pH}$ of 12-13) than oyster shell ( $\mathrm{pH} 9)$ may assist in safeguarding marine organisms from increasing ocean acidification, especially during the vulnerable juvenile stages (Mos et al., 2019). However, concerns have been raised over negative impacts of a high alkalinity on the development of other oyster reef-associated organisms (Guilbeau et al., 2003; Müllauer et al., 2015; Dennis et al., 2018). The high 
TABLE 1 | Key structural attributes of substrates that should be considered in oyster reef restoration, and their influences on ecosystem services.

\begin{tabular}{|c|c|c|c|c|}
\hline Structural characteristics & Processes affected & Ecosystem services affected & Effect on reef resilience & References \\
\hline Surface complexity & $\begin{array}{l}\text { Enhances surface area } \\
\text { available for recruitment; } \\
\text { ameliorates abiotic (e.g., heat } \\
\text { stress) and biotic (e.g., } \\
\text { predation) stressors. }\end{array}$ & Habitat provision & $\begin{array}{l}\text { Provides protection from } \\
\text { environmental stressors (i.e., } \\
\text { thermal refuge) }\end{array}$ & $\begin{array}{l}\text { Humphries et al., 2011; } \\
\text { McAfee et al., 2018a }\end{array}$ \\
\hline Reef patch size & $\begin{array}{l}\text { Determines: habitat area for } \\
\text { colonization; oyster biomass, } \\
\text { and hence filtration; reef width } \\
\text { and wave attenuation }\end{array}$ & $\begin{array}{l}\text { Habitat provision; wave } \\
\text { attenuation; maintenance of } \\
\text { clean water }\end{array}$ & $\begin{array}{l}\text { Removal of nutrients and } \\
\text { microalgae from waterways can } \\
\text { decrease likelihood of } \\
\text { eutrophication events and } \\
\text { associated mass fish kills }\end{array}$ & $\begin{array}{l}\text { Griffitt et al., 1999; } \\
\text { Harwell et al., } 2011\end{array}$ \\
\hline Reef fragmentation & $\begin{array}{l}\text { Edge to interior ratio influences } \\
\text { recruitment and predation }\end{array}$ & Habitat provision & $\begin{array}{l}\text { Higher availability of edge } \\
\text { complexity provides refuge for } \\
\text { larger species (e.g., fishes and } \\
\text { crabs) }\end{array}$ & $\begin{array}{l}\text { Abele et al., 1986; } \\
\text { Griffitt et al., 1999; } \\
\text { Sutton et al., 2007; } \\
\text { Harwell et al., } 2011\end{array}$ \\
\hline Vertical relief & $\begin{array}{l}\text { Elevates oysters above silty and } \\
\text { hypoxic bottom waters, to } \\
\text { high-flow nutrient and } \\
\text { oxygen-rich waters; influences } \\
\text { wave attenuation }\end{array}$ & $\begin{array}{l}\text { Shoreline stabilization and wave } \\
\text { attenuation }\end{array}$ & $\begin{array}{l}\text { Vertical reef accretion can } \\
\text { outpace sea level rise. Can } \\
\text { facilitate landward expansion of } \\
\text { biogenic habitats (e.g., } \\
\text { saltmarsh) }\end{array}$ & $\begin{array}{l}\text { Piazza et al., 2005; } \\
\text { Rodriguez et al., 2014; } \\
\text { Chowdhury et al., } \\
2019 \text { a }\end{array}$ \\
\hline
\end{tabular}

alkalinity of concrete may also interfere with the natural process of species adapting to lower $\mathrm{pH}$ over time (Amaral et al., 2012; Cole et al., 2016; Gray et al., 2019). Nevertheless, concrete surface texture rather than chemistry appears to be a more important determinant of oyster settlement (Potet et al., 2021).

The density and longevity of materials can also be a key determinant of their suitability for restoration, especially in dynamic environments. Without stabilization, relatively lowdensity shell materials placed in wave-swept environments are rapidly dispersed, compromising their suitability as a substrate for oyster settlement, and their utility for naturebased coastal defense. Higher-density concrete substrates, by contrast, are stable, but where these hard engineering structures attenuate waves and stabilize shorelines, they may make oyster reef restoration for shoreline stabilization purposes redundant (Morris et al., 2019). Rapidly biodegrading substrates may be desirable in environments with high spatfall and rapid reef growth. In other environments where reef development is slower, or the frequency and intensity of storms is great, substrates with longer longevity may be needed. Increasing frequency and intensity of storm events, under future climate change scenarios, may necessitate use of substrates of higher durability (Firth et al., 2013; Stocker et al., 2013).

\section{Return on Investment}

Not only do substrates vary markedly in their efficacy in promoting oyster reef growth, but they also vary in their monetary and environmental cost (Table 2). The ratio of benefits to costs will determine return on investment, an increasingly important factor driving reef design (Bersoza Hernández et al., 2018).

Natural materials typically used in the construction of lowlying reefs (i.e., oyster shells, crushed rock, limestone and clam shells) are generally cheap, as they do not require manufacturing, with their cost instead limited to transportation and deployment, and in some instances also extraction, sterilization (e.g., boiling or UV treatment of shell to remove parasites) and packaging (Goelz et al., 2020). Concrete and associated products such as Reefcrete and Econcrete are typically more expensive due to the manufacturing processes (Flower and Sanjayan, 2007; Marinković et al., 2010; Dennis et al., 2018), as are bespoke products such as BESE-elements that are manufactured at smaller economies of scale.

The environmental footprint associated with substrates also varies, and is generally less for naturally occurring materials (Table 2). Shell generally has a low environmental footprint, particularly where it is sourced from restaurants through shell recycling programs (Branigan et al., 2020) and has been appropriately treated through UV exposure (i.e., curing) or boiling, to kill any hitchhiking species or parasites (Jeffs et al., 2019; Branigan et al., 2020). Transportation of shell across large distances, extraction by dredge and/or inadequate biosecurity control may, however, inflate this. Crushed rock and limestone has a low footprint where it is sourced as a waste product from other activities, but this is increased where mining is required (Graham et al., 2017; Goelz et al., 2020). The fabrication of concrete, by contrast, releases large amounts of $\mathrm{CO}_{2}$ into the atmosphere (Achternbosch et al., 2011), uses large quantities of water (Flower and Sanjayan, 2007; Marinković et al., 2010). Reefcrete created from recycled ground granulated blast-furnace slag and Portland cement, supplemented with either hemp fibers or recycled shell material (Dennis et al., 2018) has a reduced carbon footprint, compared to standard concrete.

Consequently, in instances where natural products such as shell and rock are appropriately placed, they generally offer greater return on investment than manufactured products (Bersoza Hernández et al., 2018). However, the utilization of natural products can be limited by availability and in the case of shell, stability and longevity. Poorly stabilized shell in high waveenergy environments will not provide a suitable substrate for oyster settlement, and any benefit of a cheap and environmentally friendly substrate will be offset by poor ecological return. Hence 
TABLE 2 | Performance of substrates against key criteria for oyster reef restoration.

\begin{tabular}{|c|c|c|c|c|c|c|c|c|}
\hline Materials & $\begin{array}{l}\text { Appropriate chemical } \\
\text { cues }\end{array}$ & Biosecurity risk & Readily available & Durability & Biodegradable & $\begin{array}{l}\text { Environmental } \\
\text { footprint }\end{array}$ & Cost & References \\
\hline Shell & $\begin{array}{l}\text { Generally yes, though } \\
\text { oyster settlement onto } \\
\text { mussel shell can be low }\end{array}$ & $\begin{array}{l}\text { High; though this can } \\
\text { be reduced to low with } \\
\text { appropriate sterilization } \\
\text { of translocated shell }\end{array}$ & $\begin{array}{l}\text { Variable; can be } \\
\text { sourced from } \\
\text { aquaculture and } \\
\text { shell-recycling } \\
\text { programs }\end{array}$ & $\begin{array}{l}\text { Low-medium; needs to } \\
\text { be stabilized and in } \\
\text { wave-swept } \\
\text { environments softer } \\
\text { shells may degrade }\end{array}$ & $\begin{array}{l}\text { Yes; though where } \\
\text { stabilized in plastic } \\
\text { mesh bags this may be } \\
\text { negated }\end{array}$ & $\begin{array}{l}\text { Small; particularly when } \\
\text { sourced from local shell } \\
\text { recycling programs }\end{array}$ & Low & $\begin{array}{l}\text { O'Beirn et al., 2000; } \\
\text { Nestlerode et al., 2007; } \\
\text { Zacherl et al., 2015; } \\
\text { Graham et al., 2017; } \\
\text { Bersoza Hernández } \\
\text { et al., } 2018\end{array}$ \\
\hline $\begin{array}{l}\text { Crushed rock/ } \\
\text { stone }\end{array}$ & $\begin{array}{l}\text { Variable; yes for } \\
\text { limestone and rock with } \\
\text { calcium carbonate, no } \\
\text { for some others }\end{array}$ & $\begin{array}{l}\text { None if terrestrially } \\
\text { sourced }\end{array}$ & $\begin{array}{l}\text { Generally yes; though } \\
\text { limestone may be more } \\
\text { challenging to source }\end{array}$ & $\begin{array}{l}\text { Medium-high; } \\
\text { dependent on rock } \\
\text { type and stabilization }\end{array}$ & No & $\begin{array}{l}\text { Variable; where mined } \\
\text { can be large, but lower } \\
\text { where sourced from } \\
\text { waste }\end{array}$ & Low & $\begin{array}{l}\text { Soniat and Burton, } \\
\text { 2005; George et al., } \\
\text { 2015; Graham et al., } \\
2017\end{array}$ \\
\hline Concrete & Yes & None & Yes & High & No & $\begin{array}{l}\text { Large; water and } \\
\text { energy consumed in } \\
\text { manufacturing, } \\
\text { environmental costs } \\
\text { also associated with } \\
\text { transportation }\end{array}$ & Average & $\begin{array}{l}\text { Flower and Sanjayan, } \\
\text { 2007; Mos et al., } 2019\end{array}$ \\
\hline $\begin{array}{l}\text { Modified concrete } \\
\text { (e.g., Reefcrete or } \\
\text { Econcrete) }\end{array}$ & Yes & $\begin{array}{l}\text { Variable; inclusion of } \\
\text { shell fragments in blend } \\
\text { may introduce } \\
\text { biosecurity risks. }\end{array}$ & $\begin{array}{l}\text { Generally yes, though } \\
\text { depends on blend }\end{array}$ & High & No & $\begin{array}{l}\text { Medium-high; where } \\
\text { recycled materials are } \\
\text { included smaller than } \\
\text { for standard concrete }\end{array}$ & Average & $\begin{array}{l}\text { Perkol-Finkel and Sella, } \\
\text { 2014; Bersoza } \\
\text { Hernández et al., 2018; } \\
\text { Dennis et al., 2018; } \\
\text { Sella et al., } 2018\end{array}$ \\
\hline $\begin{array}{l}\text { Biodegradable } \\
\text { elements for } \\
\text { starting } \\
\text { ecosystems } \\
\text { (BESE-elements) }\end{array}$ & Yes & None & $\begin{array}{l}\text { Limited; presently only } \\
\text { produced in } \\
\text { Netherlands }\end{array}$ & $\begin{array}{l}\text { Low-medium; designed } \\
\text { to degrade over } \\
5-10 \text { years, dependent } \\
\text { on wave energy, } \\
\text { material is brittle }\end{array}$ & Yes & $\begin{array}{l}\text { Medium; fabricated } \\
\text { from potato waste; } \\
\text { dependent on } \\
\text { transportation }\end{array}$ & High & $\begin{array}{l}\text { Gillby et al., 2018; } \\
\text { Herbert et al., 2018; } \\
\text { BESE-elements, 2019; } \\
\text { Temmink et al., } 2020\end{array}$ \\
\hline
\end{tabular}


both cost and environmental context are key considerations in substrate selection.

\section{OYSTER SEEDING}

Historical overharvest of oyster reefs using destructive fishing methods, and more recent oyster mortality from disease and declining water quality, has reduced oyster spawning stock biomass (Beck et al., 2011; Baggett, 2014; Fitzsimons et al., 2019). Oyster seeding is required at sites where larval supply from remnant wild populations or aquaculture farms is inadequate to facilitate reef growth (Brumbaugh and Coen, 2009; Geraldi et al., 2013). Oysters may be introduced as spat (juvenile oysters) settled onto shell in hatcheries, mature (i.e., reproductively capable) adult oysters sourced from aquaculture or the wild, and/or larvae (Brumbaugh and Coen, 2009). In order for oyster reefs to persist through time, oysters must display resilience to present and projected future environmental stressors. Hence, key considerations for seeding oysters are the selection of species, populations and genotypes that are best suited to present-day and projected future environmental conditions (Figure 2).

\section{Species Selection}

There are a number of genera and species of oyster that are capable of forming reefs (Gillies et al., 2018). These differ in distribution, and hence environmental tolerances, though at many locations, multiple reef-forming species overlap in space (Gillies et al., 2018). Hence, a key consideration of restoration projects can be what species of oyster to seed reefs with. This may be a simple decision if the goal of restoration is to recover populations of a particular oyster species, or if only a single species has a distribution that overlaps with the proposed restoration site. However, where goals of oyster reef restoration are functional (i.e., shoreline stabilization, or enhancement of associated fin-fish productivity) and multiple oyster species have distributions that overlap with the proposed restoration site, the match of the species to the environment and project goals should be considered. Key considerations might include: (1) the habitat suitability of the site for oyster species under present and projected future environmental conditions; (2) the susceptibility of oyster species to disease-causing parasites and predators either presently affecting the site or predicted to into the future; (3) the capacity of the different species to deliver desired ecosystem functions now and into the future; and (4) the availability of oysters of the various species for seeding, either through established aquaculture industries, or remnant wild populations that can be harvested (Figure 2).

Reef-forming species of oyster span tropical and temperate, and marine and brackish water, varying in their environmental tolerances and sensitivity to ongoing climatic changes (Gillies et al., 2018). Hence, as the environment changes, conditions will become more suitable for some species, and less suitable for others. Species distribution modeling (SDM) can be useful in predicting how individual species might respond to this environmental change (Wiens et al., 2009), and hence, whether a given location is likely to support a particular species into the future. Nevertheless, in utilizing SDM it should be noted that SDM assumes that distributions reflect environmental niches. This may not be the case if biological factors such as disease or predation appreciably reduce, or facilitation appreciatively expands distributions over those predicted based on environmental niche (Guisan and Thuiller, 2005).

Disease and predation are also broadly regarded as key determinants of oyster distribution (Coen and Bishop, 2015; Strain et al., 2018), and due to their variable effects among oyster species, should be factored into species selection. For example, effects of Bonamia parasites appear limited to oysters of the family Ostreidae, and within this are primarily confined to Ostrea spp. (Engelsma et al., 2014). Fast-growing species of oyster can be more susceptible to predators than slow-growing species where the penalty for fast growth is a thinner shell (Bishop and Peterson, 2006). Effects of disease are expected to intensify as coastal development increasingly degrades coastal water quality, and climate change introduces the frequency of extreme events (e.g., heavy rainfall and associated fresh-water pulses, and heat waves) that stress oysters and compromise their immune system (Burge et al., 2014). By contrast, effects of predators on oysters may be diminished where coastal development negatively impacts meso-predator populations through harvest, habitat destruction and declines in water quality, or enhanced where ocean acidification results in smaller or thinner-shelled oysters (Sanford et al., 2014).

Where possible, native species should be selected over nonnative species. However, in rare instances, non-native species that are already naturalized at a location may be considered for reinstatement of lost ecosystem services. In many instances, native and non-native species of oyster display a high degree of functional redundancy in the biological communities they support and the ecosystem services they provide (e.g., Wilkie et al., 2012; Zwerschke et al., 2016, 2020). Non-native species should only be considered if: (1) environmental conditions are no longer suitable for establishment of native oysters, and/or if the non-native species displays greater capacity than native oysters to tolerate projected future environmental change; (2) the non-native species can be considered a functional analog of the native species; (3) the non-native species is already naturalized in the targeted environment; and (4) the benefits of the non-native species outweigh negative ecological or socioeconomic impacts (Ramus et al., 2017; Sotka and Byers, 2019). Such decisions should be made on a case-by-case basis with careful consideration, experimentation and analysis before they are endorsed (Sotka and Byers, 2019). Individuals for transplant should be locally sourced from naturalized populations, in order to prevent introduction of hitchhiking species, and genetic variants that may not already be present in the introduced range. In the Netherlands, where native flat oysters (Ostrea edulis) are now functionally extinct (Beck et al., 2011) and native mussel beds (Mytilus edulis) have become largely overgrown by non-native Pacific oysters, Magallana (Crassostrea) gigas (Markert et al., 2010), the nonnative oyster is being utilized for shoreline stabilization. This is because it is more suited to the present environment and is, to a large degree, functionally equivalent to the native species (de Vriend et al., 2014). 
Established aquaculture industries can be a valuable source of seed, negating the need for harvest and transplant of individuals from remnant populations (Figure 2). In instances where aquaculture industries do not presently support production of a required species, and sizeable remnant populations for transplant do not exist, new industries may be established that are focused on seed supply for restoration industries. These may take some time to establish, and genetic considerations, discussed in the following section, should also be kept in mind.

\section{Source Populations and Genetic Considerations}

In addition to the species to be utilized in restoration, the source population (and its genetic diversity) should also be considered. The historical paradigm of restoration ecology has been that transplant of locally sourced individuals into restoration sites maximizes survival, as these are adapted to the local environment (Camara and Vadopalas, 2009). Use of locally sourced transplants has also been viewed as desirable as it preserves the local gene pool (Camara and Vadopalas, 2009). Indeed, for oyster reef restoration there has been a focus on using local populations that are adapted to local diseases (Carnegie and Burreson, 2011). However, particularly for populations with limited dispersal and gene flow, or that have had their effective population size reduced or genetic composition severely modified by stressors such as harvest, exclusive use of local material may constrain rapid evolution to emerging anthropogenic and/or climatic stressors (Camara and Vadopalas, 2009). In such instances, enhancement of genetic diversity and/or genetic improvement may be achieved through supplementation of transplants with aquaculture stock, or stock acquired from other sites (Gaffney, 2006). In the restoration of terrestrial ecosystems, predictive provenancing, whereby stock is acquired from sites matching projected future conditions, or admixture provenancing, where seed is mixed from many populations throughout the distribution of the species, are approaches increasingly being applied to maximize gene flow and genetic variation (Breed et al., 2013). The benefits and risks of applying such approaches to oyster reef restoration are poorly understood, and are an area of research need. Studies of quantitative genetic variation of remnant oyster populations at a location can assist in identifying the most suitable genetic approach (Camara and Vadopalas, 2009).

Where seed is sourced from aquaculture industries, restoration projects potentially have access to selective breeding programs. Oysters are well suited to selective breeding programs due to their high fecundity and genetic variability (Gosling, 2003; Dégremont et al., 2015). Industry-based selective breeding programs have historically revolved around selection for fast growth - a trait favored by food production industries- and disease resistance, which is generally regarded as one of the largest threats to the industry (Dégremont et al., 2015). However, there is increasing interest in also breeding for resilience to heat stress and ocean acidification (Tan et al., 2020). The resulting breeding lines have, in many instances, been demonstrated to confer survival and growth benefits to cultivated oysters, when exposed to these stressors (Tan et al., 2020).
As cultivated and wild oysters are subject to many of the same stressors, it may be hypothesized that selective breeding lines developed for aquaculture may also be advantageous for oyster reef restoration. Indeed, assisted evolution-the acceleration of natural evolutionary processes, through selective breeding, epigenetic programming and manipulation of microbial communities for certain traits-is increasingly being applied to restoration of corals (Van Oppen et al., 2015). Nevertheless, a growing number of studies have demonstrated that selectively bred genotypes can be suboptimal in the wild, and consequently, do not persist or introgress into wild populations (Hare et al., 2006; Carlsson et al., 2008; Thompson et al., 2017). For example, McAfee et al. (2017) found that the trade-off for fast growth and disease resistance was resilience to warming. Hence, in order to maximize resilience to a range of stressors, a better strategy might be to maximize genetic diversity rather than select for certain genotypes.

Given the uncertainty of the performance of populations and breeding lines under future environmental conditions, it is important that oyster reef restoration programs are accompanied by appropriate programs monitoring the growth, survival and reproduction of seeded populations.

\section{RECOMMENDATIONS FOR BUILDING RESILIENT OYSTER REEFS}

This synthesis has highlighted the diversity of methods that can be applied to oyster reef restoration projects, and their applicability to varying environmental, and socio-ecological contexts. In order to maximize benefits of oyster reef restoration into the future, bespoke approaches are needed that are responsive to stakeholder goals, site conditions and present and predicted future key threatening processes. Projects that blindly apply methodologies without considering their match to present and future conditions or goals risk a higher probability of failure.

Our synthesis has highlighted that the starting point for planning any restoration project should be identifying the goals of the project (Figure 2). This is because the sites and methods that are most suitable for oyster reef restoration will vary according to the specific goals. For example, whereas projects aimed at shoreline protection might target eroding shorelines and oyster reefs of high vertical relief, those aimed at fisheries productivity might target complex low-lying forms, situated proximate to other important fish habitats such as mangroves, saltmarsh, and seagrass.

Once goals have been identified, the next step is to identify the desired life-span of the project. Where the goal is multi-decadal provision of ecosystem services, restoration suitability modeling using the best available data for present-day and projected future environmental change, should be used to identify sites that meet the physico-chemical requirements of oysters and are most likely to deliver desired ecosystem services (Figure 2). The most suitable sites may vary among oyster species and in regions that support multiple reef-building oysters, species selection can be a key criterion. Site selection should not only consider climate change but also ongoing coastal urbanization which may 
modify physico-chemical conditions and also introduce sources of estuarine-use conflict.

The next step, following site selection, is site visits and pilot studies to assess whether substrate and/or seeding is required for reef establishment. Where substrate is required, key considerations for its selection include availability, the economic and environmental cost, and the growth forms of reefs the substrate facilitates (Figure 2). Consideration of growth form is important because it influences ecosystem service delivery. Oyster species and genotypes for projects requiring seeding should be selected on the basis of their environmental suitability, resilience to environmental change, and the size and shape of reefs they form-the latter again being critical to ecosystem service delivery. Availability of stock from aquaculture or remnant wild populations can also be a key consideration.

Finally, once a site and methodology has been decided on, monitoring and evaluation of the efficacy of the project in attaining goals is critical not only for adaptive management of the project in question, but also in building a broader knowledge that will maximize the successful planning of future restoration projects.

Globally, oyster reef restoration is in its infancy. There is great potential for oyster reef restoration to restore lost biodiversity and ecosystem services, and to build resilience in coastal ecosystems to the effects of ongoing climate change

\section{REFERENCES}

Abele, L. G., Campanella, P. J., and Salmon, M. (1986). Natural history and social organization of the semiterrestrial grapsid crab Pachygrapsus transversus (Gibbes). J. Exp. Mar. Biol. Ecol. 104, 153-170. doi: 10.1016/0022-0981(86) 90102-4

Achternbosch, M., Kupsch, C., Nieke, E., and Sardemann, G. (2011). Climatefriendly production of cement: a utopian vision? GAIA Ecol. Perspect. Sci. Soc. 20, 31-40. doi: 10.14512/gaia.20.1.8

Airoldi, L., Beck, M. W., Firth, L. B., Bugnot, A. B., Steinberg, P. D., and Dafforn, K. A. (2021). Emerging solutions to return nature to the urban ocean. Ann. Rev. Mar. Sci. 13, 445-477. doi: 10.1146/annurev-marine-032020-020015

Allen, R. J., and Webb, B. M. (2011). "Determination of wave transmission coefficients for oyster shell bag breakwaters," in Proceedings of the Coastal Engineering Practice 2011 (San Diego, California), 684-697.

Alleway, H., Cook, P., Crawford, C., Creighton, C., Diggles, B., Ford, J., et al. (2015). Shellfish Reef Habitats: A Synopsis to Underpin the Repair and Conservation of Australia's Environmental, Social and Economically Important Bays and Estuaries: National Environmental Science Programme: Marine Biodiversity Hub. Townsville, QLD: James Cook University.

Amaral, V., Thompson, E. L., Bishop, M. J., and Raftos, D. A. (2012). The proteomes of Sydney rock oysters vary spatially according to exposure to acid sulfate runoff. Mar. Freshw. Res. 63, 361-369. doi: 10.1071/mf11213

Anderson, M. (1996). A chemical cue induces settlement of Sydney rock oysters, Saccostrea commercialis, in the laboratory and in the field. Biol. Bull. 190, 350-358. doi: 10.2307/1543027

Baggett, L. (2014). Oyster Habitat Restoration Monitoring and Assessment Handbook. Arlington, VA: Nature Conservancy.

Banks, J., Hedge, L. H., Hoisington, C., Strain, E. M., Steinberg, P. D., and Johnston, E. L. (2016). Sydney harbour: beautiful, diverse, valuable and pressured. Region. Stud. Mar. Sci. 8, 353-361. doi: 10.1016/j.rsma.2016. 04.007

Barbier, E. B., Hacker, S. D., Kennedy, C., Koch, E. W., Stier, A. C., and Silliman, B. R. (2011). The value of estuarine and coastal ecosystem services. Ecol. Monogr. 81, 169-193. and coastal development. The success of projects is, however, contingent on careful planning and on adaptive management that is responsive to the learnings of monitoring and evaluation programs. To design restoration projects that are resilient to and mitigate the ecological impacts of ongoing environmental change we must understand the nature of the environmental, ecological and socio-economic change that is occurring.

\section{AUTHOR CONTRIBUTIONS}

$\mathrm{AH}$ and $\mathrm{MB}$ contributed to the conception and design of the review manuscript. AH conducted literature reviews, identified areas of interest and wrote the first draft of the manuscript. MB contributed expertise on the subject matter and wrote sections of the manuscript, as well as assisting $\mathrm{AH}$ in manuscript revisions, read-through and approved the submitted version. Both authors contributed to the article and approved the submitted version.

\section{FUNDING}

AH was supported by the RTP-MRES scholarship from Macquarie University during the preparation of this manuscript. This project contributes to ARC Linkage Grant LP180100732 and to NSW Environmental Trust Grant 2018-RD-0023.

Bayraktarov, E., Saunders, M. I., Abdullah, S., Mills, M., Beher, J., Possingham, H. P., et al. (2016). The cost and feasibility of marine coastal restoration. Ecol. Appl. 26, 1055-1074. doi: 10.1890/15-1077

Beck, M. W., Brumbaugh, R. D., Airoldi, L., Carranza, A., Coen, L. D., Crawford, C., et al. (2011). Oyster reefs at risk and recommendations for conservation, restoration, and management. Bioscience 61, 107-116. doi: 10.1525/bio.2011. 61.2 .5

Bersoza Hernández, A., Brumbaugh, R. D., Frederick, P., Grizzle, R., Luckenbach, M. W., Peterson, C. H., et al. (2018). Restoring the eastern oyster: how much progress has been made in 53 years? Front. Ecol. Environ. 16:463-471. doi: $10.1002 /$ fee. 1935

BESE-elements (2019). BESE elements; Ecosystem Restoration Products. Available online at: https://www.bese-products.com/ (accessed October 15, 2019).

Bishop, M. J., Mayer-Pinto, M., Airoldi, L., Firth, L. B., Morris, R. L., Loke, L. H., et al. (2017). Effects of ocean sprawl on ecological connectivity: impacts and solutions. J. Exp. Mar. Biol. Ecol. 492, 7-30. doi: 10.1016/j.jembe.2017.01.021

Bishop, M. J., and Peterson, C. H. (2006). When r-selection may not predict introduced-species proliferation: Predation OF a nonnative oyster. Ecol. Appl. 16, 718-730. doi: 10.1890/1051-0761(2006)016[0718:wrmnpi]2.0.co;2

Bonar, D. B., Coon, S. L., Walch, M., Weiner, R. M., and Fitt, W. (1990). Control of oyster settlement and metamorphosis by endogenous and exogenous chemical cues. Bull. Mar. Sci. 46, 484-498.

Branigan, S., Fitzsimons, J., and Gillies, C. L. (2020). Modern middens: shell recycling for restoring an endangered marine ecosystem in Victoria, Australia. Ecol. Manag. Restor. 21, 198-204. doi: 10.1111/emr.12425

Breed, M. F., Stead, M. G., Ottewell, K. M., Gardner, M. G., and Lowe, A. J. (2013). Which provenance and where? Seed sourcing strategies for revegetation in a changing environment. Conserv. Genet. 14, 1-10. doi: 10.1007/s10592-0120425-z

Brumbaugh, R. D., and Coen, L. D. (2009). Contemporary approaches for smallscale oyster reef restoration to address substrate versus recruitment limitation: a review and comments relevant for the Olympia oyster, Ostrea lurida Carpenter 1864. J. Shellfish Res. 28, 147-161. doi: 10.2983/035.028.0105

Burge, C. A., Eakin, C. M., Friedman, C. S., Froelich, B., Hershberger, P. K., Hofmann, E. E., et al. (2014). Climate change influences on marine infectious 
diseases: implications for management and society. Ann. Rev. Mar. Sci. 6, 249-277. doi: 10.1146/annurev-marine-010213-135029

Burke, L., Kura, Y., Kassem, K., Revenga, C., Spalding, M., McAllister, D., et al. (2001). Coastal Ecosystems. Washington, DC: World Resources Institute.

Bushek, D., Carnegie, R., Calvo, L., and Rheault, R. (2015). Streamlining biosecurity management in the context of regional molluscan shellfish transfers. J. Shellfish Res. 34:615.

Butt, D., and Raftos, D. (2008). Phenoloxidase-associated cellular defence in the Sydney rock oyster, Saccostrea glomerata, provides resistance against QX disease infections. Dev. Comp. Immunol. 32, 299-306. doi: 10.1016/j.dci.2007. 06.006

Butt, D., Shaddick, K., and Raftos, D. (2006). The effect of low salinity on phenoloxidase activity in the Sydney rock oyster, Saccostrea glomerata. Aquaculture 251, 159-166. doi: 10.1016/j.aquaculture.2005.05.045

Byers, J. E., Cuddington, K., Jones, C. G., Talley, T. S., Hastings, A., Lambrinos, J. G., et al. (2006). Using ecosystem engineers to restore ecological systems. Trends Ecol. Evol. 21, 493-500. doi: 10.1016/j.tree.2006.06.002

Camara, M. D., and Vadopalas, B. (2009). Genetic aspects of restoring Olympia oysters and other native bivalves: balancing the need for action, good intentions, and the risks of making things worse. J. Shellfish Res. 28, 121-145. doi: 10.2983/ 035.028.0104

Carlsson, J., Carnegie, R. B., Cordes, J. F., Hare, M. P., Leggett, A. T., and Reece, K. S. (2008). Evaluating recruitment contribution of a selectively bred aquaculture line of the oyster, Crassostrea virginica used in restoration efforts. J. Shellfish Res. 27, 1117-1124. doi: 10.2983/0730-8000-27.5.1117

Carnegie, R. B., and Burreson, E. M. (2011). Declining impact of an introduced pathogen: Haplosporidium nelsoni in the oyster Crassostrea virginica in Chesapeake Bay. Mar. Ecol. Progr. Ser. 432, 1-15. doi: 10.3354/meps09221

Chapman, M., and Blockley, D. (2009). Engineering novel habitats on urban infrastructure to increase intertidal biodiversity. Oecologia 161, 625-635. doi: 10.1007/s00442-009-1393-y

Chowdhury, M. S. N., Walles, B., Sharifuzzaman, S., Hossain, M. S., Ysebaert, T., and Smaal, A. C. (2019a). Oyster breakwater reefs promote adjacent mudflat stability and salt marsh growth in a monsoon dominated subtropical coast. Sci. Rep. 9:8549.

Chowdhury, M. S. N., Wijsman, J. W., Hossain, M. S., Ysebaert, T., and Smaal, A. C. (2019b). A verified habitat suitability model for the intertidal rock oyster, Saccostrea cucullata. PLoS One 14:e0217688. doi: 10.1371/journal.pone. 0217688

Coen, L. D., and Bishop, M. J. (2015). The ecology, evolution, impacts and management of host-parasite interactions of marine molluscs. J. Invertebr Pathol. 131, 177-211. doi: 10.1016/j.jip.2015.08.005

Coen, L. D., Brumbaugh, R. D., Bushek, D., Grizzle, R., Luckenbach, M. W., Posey, M. H., et al. (2007). Ecosystem services related to oyster restoration. Mar. Ecol. Progr. Ser. 341, 303-307. doi: 10.3354/meps341303

Cole, V. J., Parker, L. M., O’Connor, S. J., O’Connor, W. A., Scanes, E., Byrne, M., et al. (2016). Effects of multiple climate change stressors: ocean acidification interacts with warming, hyposalinity, and low food supply on the larvae of the brooding flat oyster Ostrea angasi. J. Mar. Biol. 163, 125.

Coombes, M. A., La Marca, E. C., Naylor, L. A., and Thompson, R. C. (2015). Getting into the groove: opportunities to enhance the ecological value of hard coastal infrastructure using fine-scale surface textures. Ecol. Eng. 77, 314-323. doi: 10.1016/j.ecoleng.2015.01.032

Crisp, D. (1976). Settlement Responses in Marine Organisms. London: Butterworths.

de Vriend, H., van Koningsveld, M., and Aarninkhof, S. (2014). "Building with nature': the new Dutch approach to coastal and river works," in Proceedings of the Institution of Civil Engineers-Civil Engineering, (London: Thomas Telford Ltd), 18-24. doi: 10.1680/cien.13.00003

Dégremont, L., Garcia, C., and Allen, S. K. Jr. (2015). Genetic improvement for disease resistance in oysters: a review. J. Invertebr. Pathol. 131, 226-241. doi: 10.1016/j.jip.2015.05.010

Dennis, H. D., Evans, A. J., Banner, A. J., and Moore, P. J. (2018). Reefcrete: reducing the environmental footprint of concretes for eco-engineering marine structures. Ecol. Eng. 120, 668-678. doi: 10.1016/j.ecoleng.2017.05.031

Diederich, S., Nehls, G., Van Beusekom, J. E., and Reise, K. (2005). Introduced Pacific oysters (Crassostrea gigas) in the northern Wadden Sea: invasion accelerated by warm summers? Helgoland Mar. Res. 59, 97-106. doi: 10.1007/ s10152-004-0195-1
Diggles, B. (2013). Historical epidemiology indicates water quality decline drives loss of oyster (Saccostrea glomerata) reefs in Moreton Bay, Australia. N. Zeal. J. Mar. Freshw. Res. 47, 561-581. doi: 10.1080/00288330.2013.781511

Dove, M. C., and Sammut, J. (2007). Impacts of estuarine acidification on survival and growth of Sydney rock oysters Saccostrea glomerata (Gould 1850). J. Shellfish Res. 26, 519-527. doi: 10.2983/0730-8000(2007)26[519:ioeaos]2.0. $\mathrm{co} ; 2$

Duarte, C. M., Agusti, S., Barbier, E., Britten, G. L., Castilla, J. C., Gattuso, J.-P., et al. (2020). Rebuilding marine life. Nature 580, 39-51.

Duarte, C. M., Hendriks, I. E., Moore, T. S., Olsen, Y. S., Steckbauer, A., Ramajo, L., et al. (2013). Is ocean acidification an open-ocean syndrome? Understanding anthropogenic impacts on seawater pH. Estuar. Coasts 36, 221-236. doi: 10. 1007/s12237-013-9594-3

Ells, V., Filip, N., Bishop, C. D., DeMont, M. E., Smith-Palmer, T., and Wyeth, R. C. (2016). A true test of colour effects on marine invertebrate larval settlement. J. Exp. Mar. Biol. Ecol. 483, 156-161. doi: 10.1016/j.jembe.2016.07.011

Engelsma, M. Y., Culloty, S. C., Lynch, S. A., Arzul, I., and Carnegie, R. B. (2014). Bonamia parasites: a rapidly changing perspective on a genus of important mollusc pathogens. Dis. Aquat. Organ. 110, 5-23. doi: 10.3354/dao02741

Ewere, E. E., Reichelt-Brushett, A., and Benkendorff, K. (2020). The neonicotinoid insecticide imidacloprid, but not salinity, impacts the immune system of Sydney rock oyster Saccostrea glomerata. Sci. Total Environ. 742:140538. doi: 10.1016/ j.scitotenv.2020.140538

Firth, L. B., Mieszkowska, N., Thompson, R. C., and Hawkins, S. J. (2013). Climate change and adaptational impacts in coastal systems: the case of sea defences. Environ. Sci. Process. Impacts 15, 1665-1670. doi: 10.1039/c3em00313b

Fitzsimons, J., Branigan, S., Brumbaugh, R., McDonald, T., and zu Ermgassen, P. (2019). Restoration Guidelines for Shellfish Reefs. Arlington, VA: The Nature Conservancy.

Fitzsimons, J. A., Branigan, S., Gillies, C. L., Brumbaugh, R. D., Cheng, J., DeAngelis, B. M., et al. (2020). Restoring shellfish reefs: global guidelines for practitioners and scientists. Conserv. Sci. Pract. 2:e198.

Flower, D. J., and Sanjayan, J. G. (2007). Green house gas emissions due to concrete manufacture. Int. J. Life Cycle Assess. 12:282. doi: 10.1007/s11367-007-0 327-3

Fodrie, F. J., Rodriguez, A. B., Baillie, C. J., Brodeur, M. C., Coleman, S. E., Gittman, R. K., et al. (2014). Classic paradigms in a novel environment: inserting food web and productivity lessons from rocky shores and saltmarshes into biogenic reef restoration. J. Appl. Ecol. 51, 1314-1325. doi: 10.1111/1365-2664.12276

Gaffney, P. M. (2006). The role of genetics in shellfish restoration. Aquat. Living Resour. 19, 277-282. doi: 10.1051/alr:2006028

Gagnaire, B., Thomas-Guyon, H., and Renault, T. (2004). In vitro effects of cadmium and mercury on Pacific oyster, Crassostrea gigas (Thunberg), haemocytes. Fish Shellfish Immunol. 16, 501-512. doi: 10.1016/j.fsi.2003.08.007

Garside, C., Glasby, T., Coleman, M., Kelaher, B. P., and Bishop, M. (2014). The frequency of connection of coastal water bodies to the ocean predicts Carcinus maenas invasion. Limnol. Oceanogr. 59, 1288-1296. doi: 10.4319/lo.2014.59.4. 1288

George, L. M., De Santiago, K., Palmer, T. A., and Pollack, J. B. (2015). Oyster reef restoration: effect of alternative substrates on oyster recruitment and nekton habitat use. J. Coast. Conserv. 19, 13-22. doi: 10.1007/s11852-014-0351-y

Geraldi, N. R., Simpson, M., Fegley, S. R., Holmlund, P., and Peterson, C. H. (2013). Addition of juvenile oysters fails to enhance oyster reef development in Pamlico Sound. Mar. Ecol. Progr. Ser. 480, 119-129. doi: 10.3354/meps10188

Gilby, B. L., Olds, A. D., Henderson, C. J., Ortodossi, N. L., Connolly, R. M., and Schlacher, T. A. (2019). Seascape context modifies how fish respond to restored oyster reef structures. ICES J. Mar. Sci. 76, 1131-1139. doi: 10.1093/icesjms/ fsz019

Gilby, B. L., Olds, A. D., Peterson, C. H., Connolly, R. M., Voss, C. M., Bishop, M. J., et al. (2018). Maximizing the benefits of oyster reef restoration for finfish and their fisheries. Fish Fish. 19, 931-947. doi: 10.1111/faf.12301

Gillies, C. L., McLeod, I. M., Alleway, H. K., Cook, P., Crawford, C., Creighton, C., et al. (2018). Australian shellfish ecosystems: past distribution, current status and future direction. PLoS One 13:e0190914. doi: 10.1371/journal.pone. 0190914

Goelz, T., Vogt, B., and Hartley, T. (2020). Alternative substrates used for oyster reef restoration: a review. J. Shellfish Res. 39, 1-12. doi: 10.2983/035.039.0101

Gosling, E. (2003). Bivalve molluscs. Hoboken, NJ: Wiley Online Library. 
Grabowski, J. H., Brumbaugh, R. D., Conrad, R. F., Keeler, A. G., Opaluch, J. J., Peterson, C. H., et al. (2012). Economic valuation of ecosystem services provided by oyster reefs. BioScience 62, 900-909. doi: 10.1525/bio.2012.62. 10.10

Grabowski, J. H., and Peterson, C. H. (2007). Restoring oyster reefs to recover ecosystem services. Ecosyst. Eng. Plants Protists 4, 281-298. doi: 10.1016/s1875$306 x(07) 80017-7$

Graham, P. M., Palmer, T. A., and Beseres Pollack, J. (2017). Oyster reef restoration: substrate suitability may depend on specific restoration goals. Restor. Ecol. 25, 459-470. doi: 10.1111/rec.12449

Gray, M. W., Chaparro, O., Huebert, K. B., O’Neill, S. P., Couture, T., Moreira, A., et al. (2019). Life history traits conferring larval resistance against ocean acidification: the case of brooding oysters of the genus Ostrea. J. Shellfish Res. 38, 751-761. doi: 10.2983/035.038.0326

Griffitt, J., Posey, M., and Alphin, T. (1999). Effects of edge fragmentation on oyster reef utilization by transient nekton. J. Elisha Mitchell Sci. Soc. 115, 98-103.

Grizzle, R. E., Greene, J. K., Luckenbach, M. W., and Coen, L. D. (2006). A new in situ method for measuring seston uptake by suspension-feeding bivalve molluscs. J. Shellfish Res. 25, 643-650. doi: 10.2983/0730-8000(2006)25[643: anismf $] 2.0 . \mathrm{co} ; 2$

Guilbeau, B. P., Harry, F. P., Gambrell, R. P., Knopf, F. C., and Dooley, K. M. (2003). Algae attachment on carbonated cements in fresh and brackish waterspreliminary results. Ecol. Eng. 20, 309-319. doi: 10.1016/s0925-8574(03) 00026-0

Guisan, A., and Thuiller, W. (2005). Predicting species distribution: offering more than simple habitat models. Ecol. Lett. 8, 993-1009. doi: 10.1111/j.1461-0248. 2005.00792.x

Hanke, M. H., Posey, M. H., and Alphin, T. D. (2017). The influence of habitat characteristics on intertidal oyster Crassostrea virginica populations. Mar. Ecol. Progr. Ser. 571, 121-138. doi: 10.3354/meps12094

Hare, M. P., Allen, S. K., Bloomer, P., Camara, M. D., Carnegie, R. B., Murfree, J., et al. (2006). A genetic test for recruitment enhancement in Chesapeake Bay oysters, Crassostrea virginica, after population supplementation with a disease tolerant strain. Conserv. Genet. 7, 717-734. doi: 10.1007/s10592-005-9108-3

Harley, C. D., Randall Hughes, A., Hultgren, K. M., Miner, B. G., Sorte, C. J., Thornber, C. S., et al. (2006). The impacts of climate change in coastal marine systems. Ecol. Lett. 9, 228-241. doi: 10.1111/j.1461-0248.2005.00871.x

Harris, J. A., Hobbs, R. J., Higgs, E., and Aronson, J. (2006). Ecological restoration and global climate change. Restor. Ecol. 14, 170-176.

Harwell, H. D., Posey, M. H., and Alphin, T. D. (2011). Landscape aspects of oyster reefs: effects of fragmentation on habitat utilization. J. Exp. Mar. Biol. Ecol. 409, 30-41. doi: 10.1016/j.jembe.2011.07.036

Herbert, D., Astrom, E., Bersoza, A., Batzer, A., McGovern, P., Angelini, C., et al. (2018). Mitigating erosional effects induced by boat wakes with living shorelines. Sustainability 10:436. doi: 10.3390/su10020436

Hughes, D. J., Cook, E. J., and Sayer, M. D. (2005). Biofiltration and biofouling on artificial structures in Europe: the potential for mitigating organic impacts. Oceanogr. Mar. Biol. 43:123. doi: 10.1201/9781420037449.ch4

Humphries, A. T., La Peyre, M. K., Kimball, M. E., and Rozas, L. P. (2011). Testing the effect of habitat structure and complexity on nekton assemblages using experimental oyster reefs. J. Exp. Mar. Biol. Ecol. 409, 172-179. doi: 10.1016/j.jembe.2011.08.017

Hunsucker, K., Melnikov, A., Gilligan, M., Gardner, H., Erdogan, C., Weaver, R., et al. (2021). Cathodically protected steel as an alternative to plastic for oyster restoration mats. Ecol. Eng. 164:106210. doi: 10.1016/j.ecoleng.2021.106210

Huston, M. (1979). A general hypothesis of species diversity. Am. Nat. 113, 81-101. doi: $10.1086 / 283366$

Ido, S., and Shimrit, P. F. (2015). Blue is the new green-ecological enhancement of concrete based coastal and marine infrastructure. Ecol. Eng. 84, 260-272. doi: 10.1016/j.ecoleng.2015.09.016

Jeffs, A., Hancock, B., zu Ermgassen, P. S., and Pogoda, B. (2019). "Biosecurity and permitting in shellfish reef restoration," in Restoration Guidelines for Shellfish Reefs, eds J. Fitzsimons, S. Branigan, R. Brumbaugh, T. McDonald, and P. zu Ermgassen (Arlington VA: The Nature Conservancy), 30-35.

Jeppesen, R., Rodriguez, M., Rinde, J., Haskins, J., Hughes, B., Mehner, L., et al. (2018). Effects of hypoxia on fish survival and oyster growth in a highly eutrophic estuary. Estuar. Coasts 41, 89-98. doi: 10.1007/s12237-016-0169-y
Kabisch, N., Frantzeskaki, N., Pauleit, S., Naumann, S., Davis, M., Artmann, M., et al. (2016). Nature-based solutions to climate change mitigation and adaptation in urban areas: perspectives on indicators, knowledge gaps, barriers, and opportunities for action. Ecol. Soc. 21:39.

Keller, D. A., Gittman, R. K., Brodeur, M. C., Kenworthy, M. D., Ridge, J. T., Yeager, L. A., et al. (2019). Salt marsh shoreline geomorphology influences the success of restored oyster reefs and use by associated fauna. Restor. Ecol. 27, 1429-1441. doi: 10.1111/rec.12992

King, N. G., Wilmes, S. B., Smyth, D., Tinker, J., Robins, P. E., Thorpe, J., et al. (2021). Climate change accelerates range expansion of the invasive non-native species, the Pacific oyster, Crassostrea gigas. ICES J. Mar. Sci. 78, 70-81. doi: 10.1093/icesjms/fsaa189

Kraft, N. J., Adler, P. B., Godoy, O., James, E. C., Fuller, S., and Levine, J. M. (2015). Community assembly, coexistence and the environmental filtering metaphor. Funct. Ecol. 29, 592-599. doi: 10.1111/1365-2435.12345

La Peyre, M., Furlong, J., Brown, L. A., Piazza, B. P., and Brown, K. (2014). Oyster reef restoration in the northern Gulf of Mexico: extent, methods and outcomes. Ocean Coast. Manag. 89, 20-28. doi: 10.1016/j.ocecoaman.2013. 12.002

La Peyre, M. K., Serra, K., Joyner, T. A., and Humphries, A. (2015). Assessing shoreline exposure and oyster habitat suitability maximizes potential success for sustainable shoreline protection using restored oyster reefs. PeerJ 3:e1317. doi: $10.7717 /$ peerj. 1317

Lannig, G., Flores, J. F., and Sokolova, I. M. (2006). Temperature-dependent stress response in oysters, Crassostrea virginica: pollution reduces temperature tolerance in oysters. Aquat. Toxicol. 79, 278-287. doi: 10.1016/j.aquatox.2006. 06.017

Lenihan, H. S., and Peterson, C. H. (1998). How habitat degradation through fishery disturbance enhances impacts of hypoxia on oyster reefs. Ecol. Appl. 8, 128-140. doi: 10.1890/1051-0761(1998)008[0128:hhdtfd]2.0.co;2

Levinton, J., Doall, M., Ralston, D., Starke, A., and Allam, B. (2011). Climate change, precipitation and impacts on an estuarine refuge from disease. PLoS One 6:e18849. doi: 10.1371/journal.pone.0018849

Lin, N., Emanuel, K., Oppenheimer, M., and Vanmarcke, E. (2012). Physically based assessment of hurricane surge threat under climate change. Nat. Climate Change 2:462. doi: 10.1038/nclimate1389

Lotze, H. K., Lenihan, H. S., Bourque, B. J., Bradbury, R. H., Cooke, R. G., Kay, M. C., et al. (2006). Depletion, degradation, and recovery potential of estuaries and coastal seas. Science 312, 1806-1809. doi: 10.1126/science.1128035

Luckenbach, M., Harding, J., Mann, R., Nestlerode, J., Beirn, F., and Wesson, J. (1999). Oyster reef restoration in Virginia, USA: rehabilitating habitats and restoring ecological functions. J. Shellfish Res. 18:720.

Mahoney, B. M., and Noyes, G. S. (1982). Effects of petroleum on feeding and mortality of the American oyster. Arch. Environ. Contam. Toxicol. 11, 527-531. doi: $10.1007 / \mathrm{bf} 01056358$

Malham, S. K., Cotter, E., O’Keeffe, S., Lynch, S., Culloty, S. C., King, J. W., et al. (2009). Summer mortality of the Pacific oyster, Crassostrea gigas, in the Irish Sea: the influence of temperature and nutrients on health and survival. Aquaculture 287, 128-138. doi: 10.1016/j.aquaculture.2008.10.006

Mann, R., and Powell, E. N. (2007). Why oyster restoration goals in the Chesapeake Bay are not and probably cannot be achieved. J. Shellfish Res. 26, 905-917. doi: 10.2983/0730-8000(2007)26[905:worgit] 2.0.co;2

Marinković, S., Radonjanin, V., Malešev, M., and Ignjatović, I. (2010). Comparative environmental assessment of natural and recycled aggregate concrete. Waste Manag. 30, 2255-2264. doi: 10.1016/j.wasman.2010.04.012

Markert, A., Wehrmann, A., and Kröncke, I. (2010). Recently established Crassostrea-reefs versus native Mytilus-beds: differences in ecosystem engineering affects the macrofaunal communities (Wadden Sea of Lower Saxony, southern German Bight). Biol. Invas. 12, 15-32. doi: 10.1007/s10530-009-9425-4

McAfee, D., Bishop, M. J., Yu, T. N., and Williams, G. A. (2018a). Structural traits dictate abiotic stress amelioration by intertidal oysters. Funct. Ecol. 32, 2666-2677. doi: 10.1111/1365-2435.13210

McAfee, D., Cumbo, V. R., Bishop, M. J., and Raftos, D. A. (2018b). Intraspecific differences in the transcriptional stress response of two populations of Sydney rock oyster increase with rising temperatures. Mar. Ecol. Progr. Ser. 589, 115-127. doi: 10.3354/meps12455 
McAfee, D., O'connor, W. A., and Bishop, M. J. (2017). Fast-growing oysters show reduced capacity to provide a thermal refuge to intertidal biodiversity at high temperatures. J. Anim. Ecol. 86, 1352-1362. doi: 10.1111/1365-2656.12757

McDonald, T., Jonson, J., and Dixon, K. (2016). National standards for the practice of ecological restoration in Australia. Ecol. Manag. Restor. 1, 1-34.

McGranahan, G., Balk, D., and Anderson, B. (2007). The rising tide: assessing the risks of climate change and human settlements in low elevation coastal zones. Environ. Urban. 19, 17-37. doi: 10.1177/0956247807076960

Millington, R., Cox, P. M., Moore, J. R., and Yvon-Durocher, G. (2019). Modelling ecosystem adaptation and dangerous rates of global warming. Emerg. Top. Life Sci. 3, 221-231. doi: 10.1042/etls20180113

Morris, R. L., Bilkovic, D. M., Boswell, M. K., Bushek, D., Cebrian, J., Goff, J., et al. (2019). The application of oyster reefs in shoreline protection: are we over-engineering for an ecosystem engineer? J. Appl. Ecol. 56, 1703-1711. doi: 10.1111/1365-2664.13390

Mos, B., Dworjanyn, S. A., Mamo, L. T., and Kelaher, B. P. (2019). Building global change resilience: concrete has the potential to ameliorate the negative effects of climate-driven ocean change on a newly-settled calcifying invertebrate. Sci. Total Environ. 646, 1349-1358. doi: 10.1016/j.scitotenv.2018.07.379

Müllauer, W., Beddoe, R. E., and Heinz, D. (2015). Leaching behaviour of major and trace elements from concrete: effect of fly ash and GGBS. Cement Concr. Comp. 58, 129-139. doi: 10.1016/j.cemconcomp.2015.02.002

Nelson, K. A., Leonard, L. A., Posey, M. H., Alphin, T. D., and Mallin, M. A. (2004). Using transplanted oyster (Crassostrea virginica) beds to improve water quality in small tidal creeks: a pilot study. J. Exp. Mar. Biol. Ecol. 298, 347-368. doi: 10.1016/s0022-0981(03)00367-8

Nestlerode, J. A., Luckenbach, M. W., and O'Beirn, F. X. (2007). Settlement and survival of the oyster Crassostrea virginica on created oyster reef habitats in Chesapeake Bay. Restor. Ecol. 15, 273-283. doi: 10.1111/j.1526-100x.2007. 00210.x

O’Beirn, F. X., Luckenbach, M., Nestlerode, J. A., and Coates, G. M. (2000). Toward design criteria in constructed oyster reefs: oyster recruitment as a function of substrate type and tidal height. J. Shellfish Res. 19:387.

Paalvast, P. (2015). "The role of geometric structure and texture on concrete for algal and macrofaunal colonization in the marine and estuarine intertidal zone," in Proceedings of Congress on Artificial Reefs: From Materials to Ecosystems, Caen, 77-84.

Pachauri, R. K., Allen, M. R., Barros, V. R., Broome, J., Cramer, W., Christ, R., et al. (2014). Climate Change 2014: Synthesis Report. Contribution of Working Groups I, II and III to the Fifth Assessment Report of the Intergovernmental Panel on Climate Change. Geneva: IPCC.

Parker, L. M., O’Connor, W. A., Byrne, M., Dove, M., Coleman, R. A., Pörtner, H.O., et al. (2018). Ocean acidification but not warming alters sex determination in the Sydney rock oyster, Saccostrea glomerata. Proc. R. Soc. Lond. B Biol. Sci. 285:20172869. doi: 10.1098/rspb.2017.2869

Parker, L. M., Scanes, E., O’Connor, W. A., Coleman, R. A., Byrne, M., Pörtner, H.-O., et al. (2017). Ocean acidification narrows the acute thermal and salinity tolerance of the Sydney rock oyster Saccostrea glomerata. Mar. Pollut. Bull. 122, 263-271. doi: 10.1016/j.marpolbul.2017.06.052

Pawlik, J. R. (1992). Chemical ecology of the settlement of benthic marine invertebrates. Oceanogr. Mar. Biol. Ann. Rev. 30, 273-335.

Pearson, S., Windupranata, W., Pranowo, S. W., Putri, A., Ma, Y., Vila-Concejo, A., et al. (2016). Conflicts in some of the World harbours: what needs to happen next? Maritime Stud. 15, 1-23.

Perkol-Finkel, S., and Sella, I. (2014). "Ecologically active concrete for coastal and marine infrastructure: innovative matrices and designs," in Proceedings of the From Sea to Shore-Meeting the Challenges of the Sea: (Coasts, Marine Structures and Breakwaters 2013), (London: ICE publishing), 1139-1149.

Piazza, B. P., Banks, P. D., and La Peyre, M. K. (2005). The potential for created oyster shell reefs as a sustainable shoreline protection strategy in Louisiana. Restor. Ecol. 13, 499-506. doi: 10.1111/j.1526-100x.2005.00062.x

Pogoda, B., Merk, V., Colsoul, B., Hausen, T., Peter, C., Pesch, R., et al. (2020). Site selection for biogenic reef restoration in offshore environments: the Natura 2000 area Borkum reef ground as a case study for native oyster restoration. Aquat. Conserv. Mar. Freshw. Ecosyst. 30, 2163-2179. doi: 10.1002/aqc. 3405

Potet, M., Fabien, A., Chaudemanche, S., Sebaibi, N., Guillet, T., Gachelin, S., et al. (2021). Which concrete substrate suits you? Ostrea edulis larval preferences and implications for shellfish restoration in Europe. Ecol. Eng. 162:106159. doi: 10.1016/j.ecoleng.2021.106159

Powell, E. N., Gauthier, J. D., Wilson, E. A., Nelson, A., Fay, R. R., and Brooks, J. M. (1992). Oyster disease and climate change. Are yearly changes in Perkinsus marinus parasitism in oysters (Crassostrea virginica) controlled by climatic cycles in the Gulf of Mexico? Mar. Ecol. 13, 243-270. doi: 10.1111/j.1439-0485. 1992.tb00354.x

Raftos, D. A., Kuchel, R., Aladaileh, S., and Butt, D. (2014). Infectious microbial diseases and host defense responses in Sydney rock oysters. Front. Microbiol. 5:135. doi: 10.3389/fmicb.2014.00135

Ramus, A. P., Silliman, B. R., Thomsen, M. S., and Long, Z. T. (2017). An invasive foundation species enhances multifunctionality in a coastal ecosystem. Proc. Natl. Acad. Sci. U.S.A. 114, 8580-8585. doi: 10.1073/pnas.1700353114

Raymond, C. M., Frantzeskaki, N., Kabisch, N., Berry, P., Breil, M., Nita, M. R., et al. (2017). A framework for assessing and implementing the co-benefits of nature-based solutions in urban areas. Environ. Sci. Policy 77, 15-24. doi: 10.1016/j.envsci.2017.07.008

Rodriguez, A. B., Fodrie, F. J., Ridge, J. T., Lindquist, N. L., Theuerkauf, E. J., Coleman, S. E., et al. (2014). Oyster reefs can outpace sea-level rise. Nat. Climate Change 4:493. doi: 10.1038/nclimate2216

Ruesink, J. L., Lenihan, H. S., Trimble, A. C., Heiman, K. W., Micheli, F., Byers, J. E., et al. (2005). Introduction of non-native oysters: ecosystem effects and restoration implications. Ann. Rev. Ecol. Evol. Syst. 36, 643-689. doi: 10.1146/ annurev.ecolsys.36.102003.152638

Rybovich, M., La Peyre, M. K., Hall, S. G., and La Peyre, J. F. (2016). Increased temperatures combined with lowered salinities differentially impact oyster size class growth and mortality. J. Shellfish Res. 35, 101-113. doi: 10.2983/035.035. 0112

Sanford, E., Gaylord, B., Hettinger, A., Lenz, E. A., Meyer, K., and Hill, T. M. (2014). Ocean acidification increases the vulnerability of native oysters to predation by invasive snails. Proc. R. Soc. Lond. Biol. Sci. 281:20132681. doi: 10.1098/rspb. 2013.2681

Scanes, E., Scanes, P. R., and Ross, P. M. (2020). Climate change rapidly warms and acidifies Australian estuaries. Nat. Commun. 11:1803.

Schulte, D. M., Burke, R. P., and Lipcius, R. N. (2009). Unprecedented restoration of a native oyster metapopulation. Science 325, 1124-1128. doi: 10.1126/ science. 1176516

Sella, I., Perkol-Finkel, S., and Rella, A. (2018). "ECOncrete technologies: bioenhanced concrete for coastal and marine infrastructure," in Proceedings of the Coasts, Marine Structures and Breakwaters 2017: Realising the Potential, (London: ICE Publishing), 549-552.

Shaw, R., Arnold, D. C., and Stallworthy, W. B. (1970). Effects of light on spat settlement of the American oyster (Crassostrea virginica). J. Fish. Board Can. 27, 743-748. doi: 10.1139/f70-078

Sheaves, M. (2009). Consequences of ecological connectivity: the coastal ecosystem mosaic. Mar. Ecol. Progr. Ser. 391, 107-115. doi: 10.3354/meps08121

Soniat, T. M., and Brody, M. S. (1988). Field validation of a habitat suitability index model for the American oyster. Estuaries 11, 87-95. doi: 10.2307/1351995

Soniat, T. M., and Burton, G. M. (2005). A comparison of the effectiveness of sandstone and limestone as cultch for oysters Crassostrea virginica. J. Shellfish Res. 24, 483-486. doi: 10.2983/0730-8000(2005)24[483:acoteo]2.0.co;2

Soniat, T. M., Conzelmann, C. P., Byrd, J. D., Roszell, D. P., Bridevaux, J. L., Suir, K. J., et al. (2013). Predicting the effects of proposed Mississippi River diversions on oyster habitat quality; application of an oyster habitat suitability index model. J. Shellfish Res. 32, 629-638. doi: 10.2983/035.032.0302

Sotka, E., and Byers, J. (2019). Not so fast: promoting invasive species to enhance multifunctionality in a native ecosystem requires strong (er) scrutiny. Biol. Invas. 21, 19-25. doi: 10.1007/s10530-018-1822-0

Spiering, D., Kibler, K. M., and Kitsikoudis, V. (2018). "Hydrodynamic change following living shoreline restoration based on a before-after-control-impact experiment," in Proceedings of the World Environmental and Water Resources Congress 2018: Hydraulics and Waterways, Water Distribution Systems Analysis, and Smart Water: American Society of Civil Engineers, Reston, VA, 54-64.

Stewart-Sinclair, P. J., Purandare, J., Bayraktarov, E., Waltham, N., Reeves, S., Statton, J., et al. (2020). Blue restoration-building confidence and overcoming barriers. Front. Mar. Sci. 7:541700. doi: 10.3389/fmars.2020.541700

Stocker, T. F., Qin, D., Plattner, G.-K., Tignor, M., Allen, S. K., Boschung, J., et al. (2013). Climate change 2013: The Physical Science basis. Working Group 
I Contribution to the 5th Assessment Report of the Intergovernmental Panel on Climate Change. Cambridge: Cambridge University Press Cambridge.

Strain, E., Morris, R., Coleman, R., Figueira, W., Steinberg, P., Johnston, E., et al. (2018). Increasing microhabitat complexity on seawalls can reduce fish predation on native oysters. Ecol. Eng. 120, 637-644. doi: 10.1016/j.ecoleng. 2017.05.030

Strain, E. M. A., Cumbo, V. R., Morris, R. L., Steinberg, P. D., and Bishop, M. J. (2020). Interacting effects of habitat structure and seeding with oysters on the intertidal biodiversity of seawalls. PLoS One 15:e0230807. doi: 10.1371/journal. pone. 0230807

Sutton, R. J., Deas, M. L., Tanaka, S. K., Soto, T., and Corum, R. A. (2007). Salmonid observations at a Klamath River thermal refuge under various hydrological and meteorological conditions. River Res. Appl. 23, 775-785. doi: 10.1002/rra. 1026

Syvitski, J. P., Kettner, A. J., Overeem, I., Hutton, E. W., Hannon, M. T., Brakenridge, G. R., et al. (2009). Sinking deltas due to human activities. Nat. Geosci. 2:681. doi: 10.1038/ngeo629

Tan, K., Zhang, H., and Zheng, H. (2020). Selective breeding of edible bivalves and its implication of global climate change. Rev. Aquacult. 12, 2559-2572. doi: 10.1111/raq. 12458

Temmerman, S., Meire, P., Bouma, T. J., Herman, P. M., Ysebaert, T., and De Vriend, H. J. (2013). Ecosystem-based coastal defence in the face of global change. Nature 504, 79-83. doi: 10.1038/nature12859

Temmink, R. J., Christianen, M. J., Fivash, G. S., Angelini, C., Boström, C., Didderen, K., et al. (2020). Mimicry of emergent traits amplifies coastal restoration success. Nat. Commun. 11:3668.

Theuerkauf, S. J., and Lipcius, R. N. (2016). Quantitative validation of a habitat suitability index for oyster restoration. Front. Mar. Sci. 3:64. doi: 10.3389/fmars. 2016.00064

Thompson, J. A., Stow, A. J., and Raftos, D. A. (2017). Lack of genetic introgression between wild and selectively bred Sydney rock oysters Saccostrea glomerata. Mar. Ecol. Progr. Ser. 570, 127-139. doi: 10.3354/meps 12109

Van Oppen, M. J., Oliver, J. K., Putnam, H. M., and Gates, R. D. (2015). Building coral reef resilience through assisted evolution. Proc. Natl. Acad. Sci. U.S.A. 112, 2307-2313. doi: 10.1073/pnas.1422301112

Waldbusser, G. G., Voigt, E. P., Bergschneider, H., Green, M. A., and Newell, R. I. (2011). Biocalcification in the eastern oyster (Crassostrea virginica) in relation to long-term trends in Chesapeake Bay pH. Estuar. Coasts 34, 221-231. doi: 10.1007/s12237-010-9307-0

Wasson, K. (2010). Informing Olympia oyster restoration: evaluation of factors that limit populations in a California estuary. Wetlands 30, 449-459. doi: 10.1007/s13157-010-0056-4

Webb, B. M., and Allen, R. (2017). "Wave transmission through artificial reef breakwaters," in Proceedings of the Coastal Structures and Solutions to Coastal Disasters 2015: Resilient Coastal Communities. American Society of Civil Engineers, Reston, VA, 432-441.

White, J. M., Buhle, E. R., Ruesink, J. L., and Trimble, A. C. (2009). Evaluation of Olympia oyster (Ostrea lurida carpenter 1864) status and restoration techniques in Puget sound, Washington, United States. J. Shellfish Res. 28, 107-112. doi: $10.2983 / 035.028 .0101$
Wiberg, P. L., Taube, S. R., Ferguson, A. E., Kremer, M. R., and Reidenbach, M. A. (2019). Wave attenuation by oyster reefs in shallow coastal bays. Estuar. Coasts 42, 331-347. doi: 10.1007/s12237-018-0463-y

Wiens, J. A., Stralberg, D., Jongsomjit, D., Howell, C. A., and Snyder, M. A. (2009). Niches, models, and climate change: assessing the assumptions and uncertainties. Proc. Natl. Acad. Sci. U.S.A. 106(Suppl. 2), 19729-19736. doi: 10.1073/pnas.0901639106

Wilkie, E. M., Bishop, M. J., and O'Connor, W. A. (2012). Are native Saccostrea glomerata and invasive Crassostrea gigas oysters' habitat equivalents for epibenthic communities in south-eastern Australia? J. Exp. Mar. Biol. Ecol. 420, 16-25. doi: 10.1016/j.jembe.2012.03.018

Williamson, M. (1988). "Relationship of species number to area, distance and other variables," in Analytical Biogeography, eds A. A. Myers and P. S. Giller (Dordrecht: Springer), 91-115. doi: 10.1007/978-94-009-0435-4_4

Zacherl, D. C., Moreno, A., and Crossen, S. (2015). Exploring restoration methods for the Olympia oyster Ostrea lurida Carpenter, 1864: effects of shell bed thickness and shell deployment methods on shell cover, oyster recruitment, and oyster density. J. Shellfish Res. 34, 819-830. doi: 10.2983/035.034. 0311

Zimme-Faust, R. K., and Tamburri, M. N. (1994). Chemical identity and ecological implications of a waterborne, larval settlement cue. Limnol. Oceanogr. 39, 1075-1087. doi: 10.4319/lo.1994.39.5.1075

Zu Ermgassen, P. S., Spalding, M. D., Blake, B., Coen, L. D., Dumbauld, B., Geiger, S., et al. (2012). Historical ecology with real numbers: past and present extent and biomass of an imperilled estuarine habitat. Proc. R. Soc. Lond. B Biol. Sci. 279, 3393-3400. doi: 10.1098/rspb.2012.0313

Zwerschke, N., Eagling, L., Roberts, D., and O'Connor, N. (2020). Can an invasive species compensate for the loss of a declining native species? Functional similarity of native and introduced oysters. Mar. Environ. Res. 153:104793. doi: 10.1016/j.marenvres.2019.104793

Zwerschke, N., Emmerson, M. C., Roberts, D., and O’Connor, N. E. (2016). Benthic assemblages associated with native and non-native oysters are similar. Mar. Pollut. Bull. 111, 305-310. doi: 10.1016/j.marpolbul.2016.06.094

Conflict of Interest: The authors declare that the research was conducted in the absence of any commercial or financial relationships that could be construed as a potential conflict of interest.

Publisher's Note: All claims expressed in this article are solely those of the authors and do not necessarily represent those of their affiliated organizations, or those of the publisher, the editors and the reviewers. Any product that may be evaluated in this article, or claim that may be made by its manufacturer, is not guaranteed or endorsed by the publisher.

Copyright (C) 2021 Howie and Bishop. This is an open-access article distributed under the terms of the Creative Commons Attribution License (CC BY). The use, distribution or reproduction in other forums is permitted, provided the original author(s) and the copyright owner(s) are credited and that the original publication in this journal is cited, in accordance with accepted academic practice. No use, distribution or reproduction is permitted which does not comply with these terms. 